\title{
Kompetensi Pengelola Anggaran, Pemanfaatan Teknologi Informasi, Sistem Pengendalian Internal Dan Akuntabilitas Laporan Keuangan Di Kementerian Pertahanan Indonesia
}

\author{
Dewi Sundari ${ }^{1}$, JMV Mulyadi ${ }^{2}$
}

${ }^{1}$ Universitas ...

${ }^{2}$ Universitas Pancasila, Jl. Srengseng Sawah, Jagakarsa, Jakarta Selatan, 12640

INFO ARTIKEL

JEL Classsification:

M40

$J 24$

Keywords:

accountability,

competences utilization

of information

technology,

government internal

control system.

\section{ABSTRACT}

This research is conducted to see the influence of several variables that determine the accountability of financial statement in Directorate General of Defence Potential, Ministry of Defence of The Republic of Indonesia. The variables studied were the influence of the competence of budget personnel, the utilization of information technology, and the application of government internal control system. The data collection techniques of this research is used a questionnaire survey with primary data sources and the statistical methods used to test the hypotheses is multiple linear regression analysis. The result of this research are the competence of budget personnel and the application of government internal control system do not influence accountability of financial statement but utilization of information technology have influence positive and significantly to accountability of financial statement in Directorate General of Defence Potential, Ministry of Defence of The Republic of Indonesia.

\begin{abstract}
ABSTRAK
Penelitian ini dilaksanakan untuk melihat pengaruh dari beberapa variabel yang menentukan akuntabilitas laporan keuangan pada Direktorat Jenderal Potensi Pertahanan Kementerian Pertahanan Republik Indonesia. Variabel yang diteliti antara lain pengaruh kompetensi pengelola anggaran, pemanfaatan teknologi nformasi, dan penerapan sistem pengendalian internal pemerintah. Teknik pengumpulan data penelitian ini menggunakan teknik survei kuesioner dengan metode statistik yang digunakan untuk menguji hipotesis adalah melalui metode analisis regresi linear berganda. Hasil dari Penelitian ini antara lain variabel kompetensi pengelola anggaran dan penerapan sistem pengendalian internal pemerintah tidak berpengaruh terhadap akuntabilitas laporan keuangan sedangkan variabel pemanfaatan teknologi informasi terbukti berpengaruh positif dan signifikan terhadap akuntabilitas laporan keuangan Direktorat Jenderal Potensi Pertahanan Kementerian Pertahanan Republik Indonesia.
\end{abstract}

*Email Korespondensi: 'dewisundari04@gmail.com, ${ }^{2}$ mulyadi.jmv@univpancasila.ac.id 


\section{Pendahuluan}

Penyelenggaraan suatu pemerintahan yang solid, bertanggungjawab, efisien dan efektif (Good Governance) dilaksanakan dengan menjaga interaksi yang konstruktif dan bersinergi antara Pemerintah, swasta dan masyarakat. Dalam beberapa tahun ini, keinginan rakyat Indonesia untuk penyelenggaraan pemerintahan yang baik (Good Governance) semakin meningkat ditandai oleh adanya reformasi disegala bidang khususnya pengelolaan keuangan negara sebagai jawaban tuntutan akuntabilitas dan transparansi hasil kegiatan Pemerintah baik di pusat maupun di daerah. Reformasi keuangan negara ditandai dengan lahirnya paket Undang-Undang tahun 2003 dan 2004 yang mengamanatkan pentingnya tata kelola keuangan dengan baik (good governance) melalui prinsip transparansi dan akuntabilitas serta penggunaan international best practices yang disesuaikan dengan kondisi di Indonesia.

Penyelenggaraan pemerintahan yang baik (Good Governance) dapat tercapai melalui pelaksanaan prinsip-prinsip pengelolaan yang baik melalui penerapan sistem pertanggungjawaban yang tepat, jelas, terukur dan legitimate sehingga penyelenggaraan pemerintahan dan pembangunan dapat berdaya guna, berhasil guna, bersih dan bertanggung jawab. Tiga pilar elemen dasar yang saling berkaitan dalam mewujudkan suatu Good Governance menurut (Osborne and Geabler, 1992, OECD and World Bank, 2000, LAN dan BPKP, 2000; 6) antara lain Transparansi, yaitu keterbukaan dalam manajemen Pemerintah, lingkungan, ekonomi dan sosial, Partisipasi, yaitu penerapan pengambilan keputusan yang demokratis serta pengakuan atas HAM, kebebasan pers dan kebebasan mengemukakan aspirasi masyarakat serta akuntabilitas, yaitu kewajiban melaporkan dan menjawab penitip amanah untuk mempertanggungjawabkan kesuksesan maupun kegagalan.

Dalam kaitannya dengan penegakan akuntabilitas finansial, sebagaimana termaktub dalam Undang-Undang Nomor 17 Tahun 2003 tentang Keuangan Negara, Pemerintah wajib mempublikasikan laporan keuangan Kementerian/Lembaga kepada pemangku kepentingannya (stakeholder). Dalam rangka menjamin akuntabilitas laporan keuangan Kementerian/Lembaga tersebut, maka Badan Pemeriksa Keuangan (BPK) sebagai pelaksana tugas dan fungsi dalam bidang pemeriksaan keuangan negara wajib memberikan opini (pendapat profesional pemeriksa) atas kewajaran informasi yang disajikan dalam laporan keuangan Kementerian/Lembaga. Kriteria pemberian pendapat atau opini tersebut antara lain adanya kesesuaian penyusunan laporan keuangan dengan Standard Akuntansi Pemerintahan (SAP), kecukupan pengungkapan informasi keuangan dalam laporan keuangan, ketaatan terhadap peraturan perundang-undangan terkait pelaporan keuangan serta efektivitas Sistem Pengendalian Internal (SPI). Undang-Undang nomor 15 tahun 2004 tentang Pemeriksaan, Pengelolaan dan Tanggung Jawab Keuangan Negara menyatakan bahwa opini yang diberikan BPK terdiri dari Wajar Tanpa Pengecualian (WTP), Wajar Dengan Pengecualian (WDP), Tidak Wajar dan Tidak Memberikan Pendapat (Disclaimer).

Kementerian Pertahanan RI sebagai salah satu kementerian di Indonesia telah menjalankan akuntabilitas laporan keuangan sebagai komitmen Pimpinan Kementerian Pertahanan dalam penyelenggaraan Good Governance. Pengelolaan keuangan negara yang dilaksanakan oleh Kementerian Pertahanan tersebut, dari tahun ke tahun terus mengalami peningkatan dari semula mendapatkan opini Wajar Dengan Pengecualian (WDP) dari tahun 2009 sampai dengan tahun 2011, kemudian menjadi opini Wajar Tanpa Pengecualian Dengan Paragraph Penjelas (WTP-DPP), dan puncaknya pada tahun 2013 mendapat opini Wajar Tanpa Pengecualian (WTP). Predikat WTP tersebut merupakan prestasi sekaligus political will Kementerian Pertahanan RI dalam 
menjalankan pemerintahan yang akuntabel dan dapat dipertanggungjawabkan.

Namun sejak tahun 2014, pertanggungjawaban laporan keuangan Kementerian Pertahanan RI terus mengalami penurunan opini yang diterima sampai dengan tahun 2016 yaitu Wajar Dengan Pengecualian (WDP). Secara umum, penurunan opini tersebut diakibatkan oleh adanya kelemahan pada kompetensi Sumber Daya Manusia (SDM), penerapan Sistem Pengendalian Internal Pemerintah (SPIP) serta belum maksimalnya pemanfaatan terknologi informasi guna mendukung kelancaran dan ketepatan penyusunan laporan keuangan sehingga berimbas pada adanya temuan BPK.

Berbicara mengenai pengaruh antara unsur Sumber Daya Manusia (SDM), penerapan Sistem Pengendalian Intern Pemerintah (SPIP), serta pemanfaatan teknologi informasi terhadap akuntabilitas laporan keuangan, telah banyak penelitian-penelitian yang menganalisis hal tersebut antara lain oleh Kurnia (2013) dan Insani (2017) yang menyatakan bahwa kualitas sumber daya manusia berpengaruh terhadap akuntabilitas laporan keuangan. Penelitian dari Azizah (2014), Ichlas (2014), Purbasari (2017) dan Masyhur (2017) juga menyatakan bahwa Sistem Pengendalian Internal (SPI) mempengaruhi akuntabilitas laporan keuangan sedangkan penelitian mengenai pemanfaatan teknologi infomasi terkait akuntabilitas laporan keuangan pernah dilakukan oleh Gunawan(2016) yang menyatakan bahwa teknologi informasi dalam bentuk aplikasi sistem keuangan mempengaruhi akuntabilitas dari laporan keuangan itu sendiri.

Namun demikian, adanya inkonsistensi hasil penelitian seperti pada penelitian Agusti (2017) yang menyatakan bahwa Sumber Daya Manusia (SDM) dan Sistem Pengendalian Internal Pemerintah (SPIP) tidak berpengaruh terhadap akuntabilitas laporan keuangan serta hasil penelitian dari Marda (2017) dimana pemanfaatan teknologi informasi tidak berpengaruh terhadap keandalan pelaporan keuangan Pemkot Dumai ditambah dengan fenomena penurunan opini pertanggungjawaban laporan keuangan Kementerian Pertahanan RI selama tahun 2009-2016, menimbulkan ketertarikan Peneliti guna menganalisa lebih lanjut pengaruh ketiga unsur tersebut yakni kompetensi Sumber Daya Manusia (SDM), penerapan dari Sistem Pengendalian Internal Pemerintah (SPIP) serta pemanfaatan teknologi informasi terhadap laporan keuangan Kementerian Pertahanan RI.

\section{Telaah Teori dan Pengembangan Hipotesis}

Hubungan antara Kompetensi Pengelola Anggaran dengan Akuntabilitas Laporan Keuangan Kementerian.

Penelitian terdahulu mengenai adanya pengaruh Sumber Daya Manusia (SDM) terhadap akuntabilitas laporan keuangan pernah dilakukan oleh Kurnia (2013) yang menyimpulkan adanya pengaruh positif dan signifikan dari kualitas Aparatur Pemda terhadap akuntabilitas laporan keuangan di Inspektorat daerah propinsi Sumatera Barat. Begitupun dengan hasil penelitian dari Insani (2017) yang menyatakan pengembangan kapasitas Sumber Daya Manusia Pemerintah Daerah berpengaruh terhadap peningkatan transparansi dan akuntabilitas pengelolaan keuangan daerah melalui sistem pengadaan pegawai serta pengembangan melalui diklat atau non diklat yang baik sehingga pengelolaan daerah dapat dipertanggung jawabkan serta hasil penelitian dari Rozi (2017) yang menyatakan bahwa pengetahuan Sumber Daya Manusia (SDM) berpengaruh terhadap pengelolaan keuangan daerah di Kabupaten Aceh Barat. Berdasarkan uraian di atas, maka patut diduga bahwa kompetensi Pengelola Anggaran berpengaruh terhadap akuntabilitas laporan keuangan Kementerian yang dapat dihipotesiskan sebagai berikut:

H1: Kompetensi Pengelola Anggaran berpengaruh terhadap akuntabilitas laporan keuangan kementerian. 
Pemanfaatan teknologi informasi terhadap akuntabilitas laporan keuangan Kementerian.

Penelitian terdahulu mengenai pengaruh teknologi informasi terhadap akuntabilitas laporan keuangan pernah dilakukan oleh Gunawan (2016) yang menghasilkan adanya pengaruh dari pemanfaatan teknologi informasi melalui system e-budgeting terhadap akuntabilitas laporan keuangan di Pemkot Surabaya. Berdasarkan penelitian terdahulu tersebut, dapat diduga kemungkinan adanya pengaruh antara pemanfaatan teknologi informasi dengan akuntabilitas laporan keuangan Kementerian yang ditunjukkan dengan hipotesis sebagai berikut:

H2: Pemanfaatan teknologi informasi berpengaruh terhadap akuntabilitas laporan keuangan kementerian.

\section{Penerapan Sistem Pengendalian Internal Pemerintah (SPIP) terhadap akuntabilitas laporan keuangan Kementerian}

Penelitian sebelumnya mengenai pengaruh Sistem Pengendalian Internal Pemerintah (SPIP) terhadap akuntabilitas laporan keuangan pernah dilakukan oleh Masyhur (2017) yang menghasilkan bahwa penerapan Sistem Pengendalian Internal Pemerintah (SPIP) berpengaruh terhadap akuntabilitas laporan keuangan di daerah Dumai. Begitupun dengan penelitian lainya dari Rozi (2017) yang menyatakan bahwa pengendalian internal berpengaruh terhadap akuntabilitas pengelolaan keuangan daerah di Kabupaten Aceh Barat, hasil penelitian dari Purbasari (2017) dimana sistem pengendalian internal berpengaruh secara signifikan terhadap akuntabilitas laporan keuangan di Puau Jawa serta penelitian dari Ichlas (2014) yang menyatakan bahwa Sistem Pengendalian Internal Pemerintah (SPIP) berpengaruh pada akuntabilitas keuangan Pemkot Banda Aceh. Berdasarkan uraian di atas, maka dapat diduga kemungkinan adanya pengaruh antara penerapan Sistem Penelitian Internal Pemerintah (SPIP) dengan akuntabilitas laporan keuangan Kementerian dengan hipotesis sebagai berikut:

H3: Sistem Pengendalian Intern Pemerintah (SPIP) berpengaruh terhadap akuntabilitas laporan keuangan kementerian.

\section{Metode Penelitian}

Populasi dalam penelitian ini adalah personel PNS dan TNI pada Direktorat Jenderal Potensi Pertahanan Kementerian Pertahanan RI pada tahun 2017. Pengambilan sampel dalam penelitian ini menggunakan teknik purposive sampling yaitu teknik pengambilan sampel dengan menggunakan kriteria-kriteria yang telah ditentukan. Adapun kriteria-kriteria penentuan sampel yang digunakan dalam penelitian ini adalah pejabat struktural dan pejabat fungsional umum yang memiliki tugas dan fungsi dibidang pengelolaan anggaran. Berdasarkan kriteria tersebut diperoleh sampel sebanyak 70 sampel penelitian. Operasionalisasi variabel yang digunakan dalam penelitian ini dijabarkan dalam tabel berikut ini. 
Tabel 1. Operasionalisasi variabel

\begin{tabular}{|c|c|c|c|}
\hline Variabel & Ukuran & Indikator & Skala \\
\hline $\begin{array}{l}\text { Y: Akuntabilitas Laporan } \\
\text { keuangan (Referensi: } \\
\text { Mardiasmo, 2002:20) }\end{array}$ & $\begin{array}{l}\text { Kesesuaian realita } \\
\text { dengan indikator } \\
\text { akuntabilitas lap. } \\
\text { keuangan }\end{array}$ & $\begin{array}{l}\text { 1. Integritas Keuangan } \\
\text { 2. Pengungkapan } \\
\text { 3. Ketaatan pada Peraturan } \\
\text { Perundangan-undangan. }\end{array}$ & Ordinal \\
\hline $\begin{array}{l}\text { X1: Kompetensi Pengelola } \\
\text { Anggaran (Referensi: } \\
\text { Guy et.al,2002) }\end{array}$ & $\begin{array}{l}\text { Kesesuaian realita } \\
\text { dengan indikator } \\
\text { kompetensi SDM }\end{array}$ & $\begin{array}{l}\text { 1. Pengetahuan (Knowledge) } \\
\text { 2. Keterampilan (Skills) } \\
\text { 3. Sikap (Atitude) }\end{array}$ & Ordinal \\
\hline $\begin{array}{l}\text { X2: Pemanfaatan Teknologi } \\
\text { Informasi (Referensi: } \\
\text { Hamzah, 2009) }\end{array}$ & $\begin{array}{l}\text { Kesesuaian realita } \\
\text { dengan indikator } \\
\text { pemanfaatan TI }\end{array}$ & $\begin{array}{l}\text { 1. Intensitas Pemanfaatan TI } \\
\text { 2. Perawatan Dan Pemeliharaan TI } \\
\text { 3. Peralatan dan aplikasi }\end{array}$ & Ordinal \\
\hline $\begin{array}{l}\text { X3: Penerapan Sistem } \\
\text { Pengendalian Intern } \\
\text { Pemerintah (SPIP) } \\
\text { (Referensi: } \\
\text { PP No.60 Tahun 2008) }\end{array}$ & $\begin{array}{l}\text { Kesesuaian realita } \\
\text { dengan indikator } \\
\text { penerapan SPIP }\end{array}$ & $\begin{array}{l}\text { 1. Lingkungan pengendalian } \\
\text { 2. Penilaian resiko } \\
\text { 3. Kegiatan Pengendalian } \\
\text { 4. Informasi dan komunikasi } \\
\text { 5. Pemantauan Pengendalian intern }\end{array}$ & Ordinal \\
\hline
\end{tabular}

Teknik analisis dilakukan melalui uji regresi berganda melalui uji validitas dan uji realibilitas serta uji asumsi klasik yang terdiri atas uji normalitas, uji heterokedastisitas, uji multikolineritas dimana uji normalitas dilakukan dengan uji kosmogorov-Smirnov, uji multikolineritas dilakukan dengan Variance Inflation Factor (VIF), uji heterokedastisitas melalui uji gletser dan uji auto korelasi dengan membandingkan nilai durbin Watson (DW) dengan nilai DW-tabel (du-(4-du)).

Analisis yang digunakan dalam penelitian ini adalah analisis deskriptif yang menggambarkan setiap variabel. Analisis deskriptif menggunakan uji $\mathrm{F}$ untuk ketepatan fungsi regresi sampel dalam menaksir nilai aktual dapat diukur melalui Goodness of fit nya. Pengujian hipotesis $\mathrm{H} 1$ sampai dengan $\mathrm{H} 3$ dilakukan melalui uji-t dimana jika hasil uji-t menunjukkan nilai signifikansi $<0.05(\alpha=5 \%)$ maka hipotesis penelitian terbukti (Ho ditolak dan H1 diterima).

\section{Analisis Hasil dan Pembahasan}

Penelitian ini bertujuan untuk menganalisis pengaruh kompetensi pengelola anggaran, pemanfaatanTeknologiInformasisertapenerapan Sistem Pengendalian Intern Pemerintah (SPIP) terhadap akuntabilitas laporan keuangan Ditjen Potensi Pertahanan kementerian Pertahanan RI. Sampel penelitian diambil dari seluruh populasi personel PNS dan TNI dalam bidang pengelolaan anggaran sejumlah 85 orang dengan menggunakan rumus Slovin pada tingkat kelonggaran ketidakpastian pengembalian yang ditolerir sebesar $5 \%$, sehingga sampel penelitian adalah sebanyak 70 orang personel. Hasil uji asumsi klasik menunjukkan distribusi nilai residual variabel adalah normal dengan hasil normal $(0,783>0,05)$. Hasil uji multikolinearitas menunjukkan semua nilai variabel memiliki nilai variance inflation factor $>10$ sehingga tidak terjadi multikolinearitas. 
Tabel 2. Deskripsi Variabel

\begin{tabular}{lrrrr}
\hline \multicolumn{1}{c}{ Variabel } & \multicolumn{1}{c}{ Nilai } & \multicolumn{1}{c}{ Nilai } \\
& Minimum & $\begin{array}{c}\text { Nilai } \\
\text { Maksimum }\end{array}$ & $\begin{array}{c}\text { Nilai } \\
\text { Rata-Rata }\end{array}$ & $\begin{array}{c}\text { Standar } \\
\text { Deviasi }\end{array}$ \\
\hline Akuntabilitas Lap. Keu. Pemerintah (Y) & 3,41 & 4,45 & 3,842 & 0,234 \\
Kompetensi pengelola Anggaran (X1 & 2,67 & 4,87 & 3,657 & 0,473 \\
Pemanfaatan Teknologi Informasi (X2) & 2,50 & 5,00 & 3,257 & 0,514 \\
Sistem Pengendalian Internal & & & & \\
Pemerintah (X3) & 3,45 & 4,82 & 3,824 & 0,202 \\
\hline
\end{tabular}

Berdasarkan tabel di bawah ini, dapat digambarkan hasil persamaan regresi penelitian ini adalah sebagai berikut $\mathbf{Y}=\mathbf{2 , 6 6 3}+\mathbf{0 , 0 5 8 X 1}+\mathbf{0 , 2 2 9 X 2}+\mathbf{0 , 0 5 7 X 3}+\mathrm{e}$

Tabel 3. Rangkuman Hasil Pengujian

\begin{tabular}{lrrrr}
\hline \multicolumn{1}{c}{ Keterangan } & \multicolumn{1}{c}{ B } & Std. Error & t-Hitung & \multicolumn{1}{l}{ Sig. } \\
\hline Kompetensi pengelola Anggaran & 0,058 & 0,054 & 1,086 & 0,281 \\
Penerapan SPIP & 0,057 & 0,126 & 0,456 & 0,650 \\
Pemanfaatan Teknologi Informasi & 0,229 & 0,053 & 4,349 & 0,000 \\
(Constant) & 2,663 & 0,491 & 5,429 & 0,000 \\
R-Square & 0,328 & & & \\
Adjusted R-Square & 0,297 & & & \\
F-Hitung & 10,736 & & & \\
Sig.F & 0,000 & & & \\
\hline
\end{tabular}

Pengaruh Kompetensi Pengelola Anggaran terhadap Akuntabilitas Laporan Keuangan.

Hipotesis pertama (H1) penelitian ini yang menyatakan bahwa kompetensi Pengelola Anggaran berpengaruh terhadap akuntabilitas laporan keuangan Kementerian tidak terbukti berdasarkan hasil statistik uji t yaitu dengan nilai $\mathrm{t}=1,086$ dan nilai signifikansi $=0,281$. Dengan demikian, maka pernyatan Ho pada penelitian ini diterima yaitu kompetensi Pengelola Anggaran tidak berpengaruh terhadap akuntabilitas laporan keuangan Kementerian. Hal ini diperkuat dengan hasil pernyataan responden dimana hasil laporan keuangan di Direktorat Jenderal Potensi Pertahanan Kementerian Pertahanan RI tetap dapat dipertanggung jawabkan meski pengelola anggaran tidak memiliki latar belakang pendidikan formal dibidang keuangan sebagai salah satu unsur kompetensi teknis Aparatur Sipil Negara sesuai pasal 69 ayat 3 Undang Undang Nomor 5 Tahun 2014 tentang Aparatur Sipil Negara antara lain kompetensi teknis diukur dari tingkat dan spesialisasi pendidikan, pelatihan teknis fungsional, dan pengalaman bekerja secara teknis. Namun, tidak adanya kompetensi teknis tersebut dapat diatasi dengan banyaknya pengalaman tugas serta pelatihan bidang keuangan dan anggaran yang dimiliki Pengelola Anggaran sehingga tetap mampu melaksanakan tugas dan fungsi jabatannya dalam pengelolaan keuangan. Hasil penelitian ini mendukung hasil penelitian sebelumnya dari Agusti (2017) yang menyatakan bahwa kualitas Sumber Daya Manusia (SDM) tidak berpengaruh terhadap kemungkinan tingginya akuntabilitas dan transparansi Kementerian/Lembaga yang 
disebabkan adanya ketidakseimbangan jumlah lulusan diklat PPAKP dengan jumlah satker di Kementerian sampel. Namun, hasil penelitian ini tidak sejalan dengan sebagian besar hasil penelitian sebelumnya antara lain penelitian oleh Kurnia (2013) yang menyatakan bahwa kualitas Aparatur Pemerintah di Inspektorat $\mathrm{Kab} /$ Kota Sumatera Barat berpengaruh secara positif dan signifikan terhadap akuntabilitas laporan keuangan di Satuan Kerja tersebut yang dibuktikan dengan hasil laporan keuangan daerah yang akuntabel dari dukungan Aparatur Pemerintah yang kompeten dan professional. Selanjutnya hasil penelitian dari Insani (2017) juga menyatakan bahwa pengembangan kapasitas Sumber Daya Manusia Pemerintah Daerah berpengaruh terhadap peningkatan transparansi dan akuntabilitas pengelolaan keuangan daerah melalui sistem pengadaan pegawai serta pengembangan melalui diklat atau non diklat yang baik sehingga pengelolaan daerah dapat dipertanggung jawabkan serta hasil penelitian dari Rozi (2017) juga menyatakan bahwa pengetahuan Sumber Daya Manusia (SDM) berpengaruh terhadap pengelolaan keuangan daerah di Kabupaten Aceh Barat. Hasil dari penelitian ini juga membantah teori yang dinyatakan oleh Prihandono (2009) yaitu bahwa tanpa Sumber Daya Manusia (SDM) yang berkualitas, pemerintahan tidak akan berjalan sesuai dengan keinginan dan harapan menuju sebuah target tujuan serta peran SDM mutlak sangat krusial mulai dari perencanaan hingga pelaksanaan seluruh kegiatan dalam pemerintahan.

\section{Pengaruh Pemanfaatan Teknologi Informasi Terhadap Akuntabilitas Laporan Keuangan Kementerian.}

Hipotesis kedua (H2) dalam penelitian ini yang menyatakan bahwa pemanfaatan teknologi informasi berpengaruh terhadap akuntabilitas laporan keuangan di Direktorat Jenderal Potensi Pertahanan Kementerian Pertahanan RI terbukti dengan nilai uji $\mathrm{t}=4,349$ dan nilai signifikansi $=0,000$ pada hasil uji statistik. Hasil kuesioner juga menunjukkan fakta bahwa pemanfaatan teknologi informasi telah diterapkan dengan maksimal dalam pelaksanaan tugas dan fungsi bidang pengelolaan anggaran di Direktorat Jenderal Potensi Pertahanan Kementerian Pertahanan melalui penggunaan aplikasi sistem penganggaran yang terintegrasi serta dukungan jaringan internet yang baik sebagai penunjang kegiatan untuk membantu kelancaran komunikasi data dan informasi antar pemangku kepentingan sehingga laporan keuangan Direktorat Jenderal Potensi Pertahanan Kementerian Pertahanan RI yang dihasilkan relevan, akuntabel dan dapat diandalkan.

Pada pasal 4 Undang-undang RI nomor 11 Tahun 2008 tentang Informasi dan Transaksi Elektronik menyatakan bahwa salah satu tujuan pemanfaatan teknologi informasi dan transaksi elektronik adalah untuk meningkatkan efektivitas dan efisiensi pelayanan publik. Penggunaan sistem e-audit sebagai bagian dari teknologi informasi dalam pemeriksaan buktibukti pertanggung jawaban keuangan berbasis internet bahkan telah berhasil menempatkan laporan keuangan Direktorat Jenderal Potensi Pertahanan Kementerian Pertahanan RI periode 2017 sebagai laporan keuangan terbaik versi Inspektorat Jenderal Kementerian Pertahanan RI. Hasil penelitian ini sejalan dengan hasil penelitian dari Gunawan (2016) antara lain pemanfaatan teknologi informasi melalui sistem e-budgeting berpengaruh terhadap akuntabilitas sistem anggaran di Pemkot Surabaya yang meningkatkan tingkat kepercayaan masyarakat kepada Pemerintah terkait anggaran, namun sebaliknya hasil penelitian ini tidak sejalan dengan hasil penelitian dari Marda (2017) yaitu bahwa pemanfaatan Teknologi Informasi tidak berpengaruh terhadap keandalan pelaporan keuangan Pemkot Dumai.

Pengaruh Penerapan Sistem Pengendalian Internal Pemerintah (SPIP) Terhadap Akuntabilitas Laporan Keuangan Kementerian. 
Pengaruh Penerapan Sistem Pengendalian Internal Pemerintah (SPIP) Terhadap

Akuntabilitas Laporan Keuangan
Kementerian.

Hipotesis ketiga (H3) yang menyatakan bahwa penerapan Sistem Pengendalian Internal Pemerintah (SPIP) berpengaruh terhadap akuntabilitas laporan keuangan di Direktorat Jenderal Potensi Pertahanan Kementerian Pertahanan RI tidak terbukti berdasarkan nilai uji $\mathrm{T}=0,456$ dan nilai signifikansi $=0,650$ dari hasil uji statistik sehingga dengan demikian pernyatan Ho dterima yaitu penerapan Sistem Pengendalian Internal Pemerintah (SPIP) tidak berpengaruh terhadap akuntabilitas laporan keuangan di Direktorat Jenderal Potensi Pertahanan Kementerian Pertahanan RI. Dari hasil data responden kuesioner penelitian juga menunjukkan meskipun komitmen Pimpinan rendah dalam sistem reward and punishment pelaksanaan tugas sebagai bagian dari unsur pemantauan pengendalian, namun hal tersebut tidak mempengaruhi akuntabilitas laporan keuangan Direktorat Jenderal Potensi Pertahanan Kementerian Pertahanan RI karena adanya penggunaan sistem keuangan yang terintegrasi antara lain Sistem Informasi Manajemen dan Akuntansi Barang Milik Negara (SIMAK-BMN) dan Sistem Akuntansi Instansi Berbasis Akrual (SAIBA) sehingga mampu meminimalisir kesalahan input data transaksi keuangan yang diakibatkan oleh kelalaian personel yang diakibatkan oleh kurangnya motivasi.

Sistem Informasi Manajemen Akuntansi Barang Milik Negara (SIMAK-BMN) adalah sebuah aplikasi sistem informasi yang dibuat oleh Kementerian Keuangan sebagai sub sistem dari Sistem Akuntansi Instansi (SAI) berupa rangkaian prosedur yang saling berhubungan untuk digunakan oleh Satuan Kerja milik Pemerintah guna menghimpun, memproses, mengolah dan melaporkan transaksi Barang Milik Negara (BMN) dengan bertujuan untuk menghasilkan informasi untuk penyusunan Neraca, Laporan BMN serta laporan manajerial lainnya sesuai dengan ketentuan yang berlaku. Barang Milik Negara (BMN) itu sendiri berdasarkan Peraturan Pemerintah Nomor 27 Tahun 2014 mengenai Pengelolaan Barang Milik Negara/Daerah adalah semua barang yang dibeli atau diperoleh atas beban Anggaran Pendapatan dan Belanja Negara (APBN) atau berasal dari perolehan lainnya yang sah. Aplikasi SIMAKBMN disajikan untuk meningkatkan pemahaman dan kontrol yang sistematis bagi personel dalam tugas dan tanggung jawabnya di organisasi.

Sistem Akuntansi Instansi Berbasis Akrual (SAIBA) adalah sebuah aplikasi yang dibuat dan dikembangkan oleh Direktorat Jenderal Perbendaharaan Kementerian Keuangan dan merupakan sub sistem dari Sistem Akuntansi Instansi (SAI) yang digunakan dalam proses penyusunan laporan keuangan instansi. Aplikasi SAIBA ini bertujuan untuk menjadi pedoman bagi para penyusun laporan keuangan di Kementerian/Lembaga untuk melaksanakan sistem akuntansi pemerintah berbasis akrual sehingga laporan keuangan yang dihasilkan lebih akuntabel dan berkualitas. Aplikasi SIMAK- BMN dan SAIBA harus bekerja secara simultan sehingga dapat terjalin check and balance antara transaksi dalam masing-masing aplikasi dimaksud.

Perlu disadari bahwa manusia adalah mahluk yang rentan terhadap tekanan masalah akibat rendahnya motivasi seperti pada kendala minimnya komitmen Pimpinan dalam sistem reward and punishment yang berdampak sistemik pada pelaksanaan tugas dan fungsi penyusunan laporan keuangan di Direktorat Jenderal Potensi Pertahanan Kementerian Pertahanan RI. Sistem reward and punishment menurut Marika (2015) sangat diperlukan guna memotivasi pegawai untuk bisa mengeluarkan seluruh kemampuannya dalam rangka pencapaian tujuan organisasi. Guna mengatasi masalah tersebut, penggunaan sistem aplikasi SIMAK-BMN dan SAIBA ternyata bukan hanya mampu meminimalisir human error yang diakibatkan oleh masalah namun sekaligus 
mampu memberikan effisiensi bagi Sumber Daya Manusia (SDM).

Ada aplikasi system informasi proses pengolahan data transaksi tidak perlu lagi dilaksanakan secara manual yang berisiko menimbulkan resiko kesalahan. Proses penginputan data kedalam aplikasi pun hanya membutuhkan satu atau dua orang personel dengan keahlian khusus dalam pengoperasian aplikasi saja sehingga dapat dialihkan untuk melaksanakan tugas dan fungsi lain yang belum optimal dikarenakan keterbatasan Sumber Daya Manusia (SDM) dalam Satuan Kerja dimaksud. Kompetensi Pengelola Anggaran, pemanfaatan Teknologi Informasi serta penerapan Sistem Pengendalian Internal Pemerintah (SPIP) terhadap akuntabilitas laporan keuangan di Direktorat Jenderal Potensi Pertahanan Kementerian Pertahanan RI hanya mempengaruhi sebesar $29,7 \%$ sedangkan sisanya sebesar $70,3 \%$ dipengaruhi oleh faktor-faktor lain misalkan komitmen organisasi, penggunaan Standar Akuntansi Pemerintah (SAP) dan lainlain.

Hasil penelitian ini memiliki keterbatasan antara lain hanya menggunakan satu sumber data yaitu sumber data primer, hanya menggunakan teknik survey melalui penyebaran kuesioner tanpa adanya pendampingan kepada responden yang menungkinkan adanya salah tafsir sehingga hasil data kuesioner menjadi tidak obyektif dan relevan. Keterbatasan lainnya adalah cakupan wilayah dalam penelitian ini masih terbatas pada satu satuan kerja sehingga dirasa belum maksimal untuk menggambarkan hasil penelitian laporan keuangan sebuah kementerian. Kuantitas dan variasi variabel bebas dalam penelitian ini masih terbatas jika dihadapkan pada banyaknya faktor penentu akuntabilitas sebuah laporan keuangan. Implikasi riset pada satuan kerja Ditjen Pothan Kementerian Pertahanan RI diharapkan dapat menciptakan lingkungan kerja di Direktorat Jenderal Potensi Pertahanan Kementerian Pertahanan RI yang berbasis teknologi informasi bukan hanya dalam bidang pengelolaan anggaran namun disegala bidang guna kelancaran pelaksanaan tugas, peningkatan budaya organisasi dengan menanamkan kesadaran pentingnya teknologi informasi guna kelancaran dan kemudahan pelaksanaan tugas dan fungsi personel sehari-hari. Perlu kebijakan pimpinan dalam meningkatkan kompetensi pengelola anggaran melalui pembinaan personel yang konsisten dan berkesinambungan dimulai dari sistem penempatan personel sesuai latar belakang pendidikan bidang keuangan, pengembangan karir melalui terbukanya kesempatan rotasi dan promosi jabatan personel serta keikutsertaan dalam workshop, kursus maupun pelatihan bidang keuangan guna peningkatan wawasan pengetahuan dan keterampilan personel. Kegiatan pelatihan diharapkan mampu menghasilkan pengelola anggaran yang kompeten dalam menyusun laporan keuangan Direktorat Jenderal Potensi Pertahanan Kementerian Pertahanan RI yang akuntabel di masa depan. Begitu pula diperlukan komitmen tegas Pimpinan dalam aturan reward and punishment di Direktorat Jenderal Potensi Pertahanan Kementerian Pertahanan RI terkait pelaksanaan tugas fungsi sesuai Sistem Operational Procedure (SOP) yang ditetapkan sebagai peningkatan penerapan Sistem Pengendalian Internal Pemerintah (SPIP) guna terwujudnya laporan keuangan yang dapat diandalkan dan dapat dipertanggung jawabkan.

Hasil penelitian ini telah mendukung hasil penelitian dari Agusti (2017) yang menemukan bahwa kelemahan internal kontrol tidak berpengaruh terhadap akuntabilitas dan transparansi Kementerian/Lembaga serta hasil penelitian dari Sari (2017) yang menyatakan bahwa Sistem Pengendalian Internal Pemerintah (SPIP) tidak berpengaruh terhadap akuntabilitas laporan keuangan sebagai penerapan Good Governance. Namun demikian, penelitian ini tidak mendukung hasil penelitian dari Masyhur (2017) yang menyatakan bahwa ternyata penerapan Sistem Pengendalian Internal Pemerintah (SPIP) berpengaruh terhadap 
akuntabilitas laporan keuangan di daerah Dumai. Begitupun dengan penelitian lainya antara lain dari Rozi (2017) yang menyatakan bahwa pengendalian internal berpengaruh terhadap akuntabilitas pengelolaan keuangan daerah di Kabupaten Aceh Barat, penelitian dari Purbasari (2017) dimana sistem pengendalian internal berpengaruh secara signifikan terhadap akuntabilitas laporan keuangan di Pulau Jawa serta penelitian dari Ichlas (2014) yang menyatakan bahwa Sistem Pengendalian Internal Pemerintah (SPIP) berpengaruh pada akuntabilitas keuangan Pemkot Banda Aceh.

\section{Simpulan, Keterbatasan Dan Implikasi Hasil Penelitian}

Berdasarkan hasil penelitian ini, dapat disimpulkan bahwa pemanfaatan Teknologi Informasi berpengaruh secara signifikan terhadap akuntabilitas laporan keuangan di Direktorat Jenderal Potensi Pertahanan Kementerian Pertahanan RI sedangkan kompetensi Pengelola Anggaran serta penerapan Sistem Pengendalian Internal Pemerintah (SPIP) tidak berpengaruh terhadap akuntabilitas laporan keuangan pada Direktorat Jenderal Potensi Pertahanan Kementerian Pertahanan RI meskipun jika variabel kompetensi Pengelola Anggaran, pemanfaatan Teknologi Informasi serta penerapan Sistem Pengendalian Internal Pemerintah (SPIP) jika bersama-sama secara simultan dapat mempengaruhi akuntabilitas laporan keuangan pada Direktorat Jenderal Potensi Pertahanan Kementerian Pertahanan RI.

Sedangkan untuk penelitian selanjutnya, implikasi yang terjadi yaitu perlunya penggabungan data primer dan data sekunder guna mendapatkan hasil penelitian yang lebih detail dan relevan, memperluas cakupan wilayah dalam penelitian menjadi seluruh satuan kerja dalam kementerian guna menghasilkan penelitian yang lebih akurat, penambahan kuantitas dan variasi dari variabel bebas dalam penelitian selanjutnya terutama penggunaan variabel yang menjadi trend saat itu sebagai salah satu penentu akuntabilitas sebuah laporan keuangan, penggunaan teknik pengamatan lansung selain survey kuesioner sebagai teknik pengumpulan data pada penelitian selanjutnya guna menghasilkan data yang obyektif dan relevan serta perlunya penyesuaian materi kuesioner dan pendampingan personal untuk pemahaman responden terhadap materi pernyataan.

\section{Daftar Referensi}

Kurnia, I., 2013. Pengaruh Sistem Akuntansi Keuangan Daerah dan Kualitas Aparatur Pemerintah Terhadap Akuntabilitas Keuangan di Inspektorat Kota, Propinsi Sumatera Barat., Jurnal Akuntansi, Sumatera Barat.

Azizah, N., 2014. Pengaruh Penyajian dan Aksesibilitas Laporan Keuangan Serta Sistem Pengendalian Internal Pemerintah Terhadap Transparansi dan Akuntabilitas Pengelolaan Keuangan Daerah di SKPD Kabupaten Lamongan, Jurnal Akuntansi, Jawa Timur.

Ichlas M., 2014. Pengaruh Penerapan Standar Akuntansi Pemerintahan, Sistem Pengendalian Internal Pemerintah dan Aksesibilitas Laporan Keuangan Terhadap Akuntablitas Keuangan Pemerintah Kota Banda Aceh. e-Jurnal Akuntansi, Aceh.

Marda, G.S. 2015. Pengaruh Sumber Daya Manusia, Pemanfaatan Teknologi Informasi dan Pengawasan Keuangan Daerah Terhadap Akuntabilitas Pelaporan Keuangan Pemkot Dumai

Gunawan, D.R., 2016. Faktor Determinan Akuntabilitas dan Transparansi Kementerian/ Lembaga. Jurnal Akuntansi, Jawa.

Asfiryati, D., 2017. Pengaruh Penerapan Sistem Akuntansi Keuangan Daerah dan Penyajian Laporan Keuangan Terhadap Akuntabilitas Pengelolaan Keuangan Daerah Dengan Sistem Pengendalian Intern Sebagai 
Variabel Intervening di SKPD Pemda Dumai. Jurnal Bisnis dan Ekonomi, Riau.

Sari, W.N., 2017. Pengaruh Kinerja Aparatur Pemerintah Daerah, Pengelolaan Keuangan Daerah, SPIP dan Komitmen Organisasi Terhadap Penerapan Good Governance (Akuntabilitas Keuangan) di SKPD Kab. Rokan Hulu Jurnal Akuntansi, Jambi.

Masyhur, M., 2017. Pengaruh Penyajian Laporan

Keuangan Daerah, Aksesibilitas Laporan Keuangan Daerah dan Pengendalian Internal Terhadap Transparansi dan Akuntabilitas Pengelolaan Keuangan Daerah Kota Dumai. Jurnal Akuntansi, Riau.

Purbasari, H., 2017. Pengaruh Desentralisasi Fiskal, Sistem Pengendalian Internal dan Kinerja Pemda Terhadap Akuntabilitas Laporan Keuangan beberapa Pemkot di Pulau Jawa. Jurnal Akuntansi, Jawa.

Agusti, A.F., 2017. Penerapan Sistem TI (E-Budgeting) Terhadap Transparansi dan Akuntabilitas Keuangan Publik di Pemkot Surabaya. Jurnal Akuntansi, Jawa.

Insani, I. 2017. Pengembangan Kapasitas SDM Pemda Dalam Rangka Peningkatan Transparansi dan Akuntabilitas Pengelolaan Keuangan Daerah. Jurnal Akuntansi, Jawa.

Rozi, M. 2017. Pengaruh Pengetahuan Pejabat Penatausahaan Keuangan Satuan Kerja Perangkat Kabupaten (PPK SKPK). Keterampilan, dan Pengawasan Internal Terhadap Akuntabilitas Pengelolaan Keuangan Daerah.
Republik Indonesia, 1999. UndangUndang Nomor 28 Tahun 1999 tentang Penyelenggaraan Negara yang Bersih dan Bebas dari Korupsi, Kolusi dan Nepotisme. , 2004. Undang-Undang Nomor 15 Tahun 2004 tentang Pemeriksaan Pengelolaan dan Tanggung Jawab Keuangan Negara.

, 2005. Undang-Undang Nomor 24 Tahun 2005 tentang Standar Akuntansi Pemerintahan. , 2006. Undang-Undang Nomor 15 Tahun 2006 tentang Badan Pemeriksa Keuangan. , 2008. Peraturan Pemerintah Nomor 60 Tahun 2008 tentang Sistem Pengendalian Intern Pemerintah. 2014. Peraturan Presiden Nomor 29 Tahun 2014 tentang Sistem Akuntabilitas Kinerja Instansi Pemerintah.

2015. Peraturan Presiden Nomor 01 Tahun 2015 tentang Reviu Laporan Keuangan Kementerian Pertahanan dan TNI.

2014. Peraturan Menteri Pertahanan RI Nomor 21 Tahun 2014 tentang Sistem Pengendalian Program dan Anggaran Pertahanan Negara. , 2014. Peraturan Menteri Pertahanan RI Nomor 58 Tahun 2014 tentang Organisasi dan Tata Kerja Kementerian Pertahanan. , 2014. Peraturan Menteri Pertahanan RI Nomor 59 Tahun 2014 tentang Jabatan Fungsional Umum dan Fungsional Tertentu Kementerian Pertahanan. 